\title{
Teacher-Trainees' Perception of Guidance Services in Colleges of Education in the Volta Region, Ghana
}

\author{
Hayford Daniel Adzakpa* \\ ${ }^{1}$ St. Francis College of Education, Hohoe Ghana \\ Department of Education Studies, Post office Box 100, Hohoe Ghana \\ Eric Nyarko-Sampson \\ University of Cape Coast, Cape Coast Ghana, Department of Guidance and Counselling \\ University Post Office, Cape Coast Ghana \\ John Ofori Attram \\ University of Cape Coast, Cape Coast Ghana \\ Department of Guidance and Counselling, University Post Office, Cape Coast Ghana
}

\begin{abstract}
Students need guidance and counselling at various levels of their educational development. The general purpose of this study was to find out teacher-trainees' perception of guidance services offered in Colleges of Education in the Volta Region of Ghana. The research study was guided by Existential theory and Humanistic person-centred theory. The study is a quantitative research which employed descriptive survey design. A sample size of 346 respondents made up of teacher-trainees was selected from seven Colleges of Education in the Volta Region using a multi-stage sampling procedure with purposive, quota, convenience and simple random sampling techniques. Data was collected with a 55-item researcher-made questionnaire with reliability coefficient of 0.89 alpha and content validity was established for the items. One-Way Analysis of Variance (ANOVA) and Independent samples $\mathrm{t}$-test were used to analyze the four research hypothesis stated for the study. The statistical packages for social sciences (SPSS) software application were used to test hypothesis at 0.05 significant level. The study reveals that guidance and counselling needs of teacher-trainees is the same for male and female. It was recommended that Ghana Education Service should ensure that trained and qualified counsellors are posted to the colleges to offer services that will meet the needs of teacher-trainees.
\end{abstract}

Keywords: Teacher-trainees, Perceptions, Guidance services, Colleges of Education.

DOI: $10.7176 /$ RHSS/9-24-06

Publication date: December $31^{\text {st }} 2019$

\section{Introduction}

Guidance and counselling is a professional field which has a broad range of activities and services aimed at assisting individuals to understand themselves, their problems, their school environment and their world (Egbochuku, 2008; Oniye \& Alawaneye, 2008; Eyo, Joshua \& Esuong, 2010; Lunenburg, 2010). Farrant (2004) opines that education is the total process of human learning by which knowledge is imparted, faculties trained and skills developed probably through schooling. Guidance and counselling being an integral component of education has also gone through significant transformations in the world and Ghana's educational system.

Gysbers and Henderson (2001) provide a historical outlook on the development of guidance and counselling. They surmised that it was introduced during the industrial revolution in the United States of America. This was a period of rapid industrial growth, social protests, social reform and utopian idealism. Some African countries (Uganda, Malawi, South Africa and Nigeria) also have policies on guidance services. Rutondoki (2001) points out that the Ugandan White Paper on Education demands that career guidance and counselling be established in all secondary schools.

Just as in other African countries, in Ghana, Essuman (2015) reports that from the 1970s up to 2010, there has been a number of government policy statements or directives on the establishment and development of guidance and counselling programmes in the nation's educational institutions. Historically, Numale (2007) stated that in Ghana adults and significant individuals (traditional chiefs, family heads and religious leaders) in the Ghanaian society gave guidance in the form of an advice and sharing of wisdom. This implies that the concept of guidance and counselling was not new in Ghanaian society, but as it was not formalized, practitioners are more likely to lead individuals into problems since not all wisdom fits all situations.

The existentialists believed that meaninglessness, anxiety, isolation and freedom/responsibility are central to human experiences and underlie most psychological problems (Yalom, 1980). Yalom stated that in attempt to find meaning, when we choose our values, which everyone does, we are assembling our own unique meaning of life. Therefore experiencing meaninglessness and establishing values are part of a meaningful life, which are issues that become the heart of guidance and counselling. As Frankl (1978) stated Man's search for meaning. According 
to May (1967), anxiety is the apprehension cued off by a threat to some value which the individual holds essential to his existence as a self. In addition, anxiety arises from our personal need to survive, to preserve our being and to assert our being in the face of challenges or death (May\& Yalom, 2005). This anxiety is part and parcel of individuals, the unavoidable part of human nature. For this reason individual seek guidance and counselling to overcome the anxiety.

The existentialists postulated that, part of human condition, is the experience of isolation (aloneness). The sense of isolation comes when individuals recognized that they cannot depend on anyone else for our own confirmation. That is, we alone must give a sense of meaning to live and we alone must decide how we will live (Corey, 2009). In this case, the individuals' isolation draws attention of significant people to realize that the individual was undergoing some challenges therefore need guidance services. According to Corsini and Wedding (2000), freedom refers to the fact that the human being is responsible for and the author of his or her own world, own life design, and own choices and actions. This implies in the guidance and counselling process client should be encouraged to stand by their decisions, defend and bear the consequences that may come from their decisions. The human being as Satre (1956) put it is condemned to freedom. Corsini and Wedding (2000) stated that congruence, unconditional positive regard and empathy represent the basic concept of humanistic person-centred theory; these are qualities a counsellor should provide to clients when offering guidance services.

Theorists interested in perception are Gestalt psychologists, Carl Rogers, Albert Ellis and Alfred Adler. For instance Rogers's theory states that individuals perceive the world in a unique phenomenological way so that no two people's perceptions of the world are the same (Corey, 2009). Ellis emphasizes that individuals are thinking beings with the capacity to be rational or irrational. To understand the individuals, it is best to listen to their 'selftalk' which contains how they perceive events especially (negative ones) in their experiences shrouded in belief systems (Corsini \& Wedding, 2000). Adler assumes that people experience reality as they perceive it and according to their own private logic. Hence the individual's sense of identity, views of the world, interpretations of the relationship between the individual and the environment remain facets of his lifestyle which influence his behaviour (Corsini \& Wedding, 2000). From the views of these theorists, people may perceive guidance services depending on their present or past experience. This experience may make them perceive counselling in a negative or positive light. The existential theory, humanistic person-centred theory and theories on perceptions' key concepts and realities gave more understanding as to clients' perception of guidance and counselling, why clients came for guidance services, what they should do and qualities that a counsellor should have to assist clients overcome their challenges.

Guidance is the process of helping individuals to understand themselves and their world (Shertzer \& Stone, 1976). Guidance is the process of helping individuals to understand themselves and direct their efforts in a way that will enable them to use potentials so as to achieve personal satisfaction and thereby make themselves useful to society. According to Biswalo (1996), guidance is a term used to denote the process of helping an individual to gain self-understanding and self-direction (self-decision making) so that he can adjust maximally to home, schools and community environment. The individual in this definition refers to the client, counsellee, pupils, students or teacher-trainees in Colleges of Education setting where the guidance programme is offered. According to Obadofin (1997), Guidance is the assistance given to the individuals in making intelligent choices and adjustments. It is based on the democratic principle that it is the duty and the right of every individual to choose his or her own way in life in so far as his choice does not interfere with the right of others. Taylor and Buku (2006) defined guidance as, the systematic professional process of helping the individual through educative and interpretive procedure to gain the better understanding of his/her own characteristics and potentialities and to relate himself or herself to more satisfactorily to social requirements and opportunities.

Counselling is the process of helping an individual to accept and use information and advise so that he can either solve his present problems or cope with it successfully (Biswalo, 1996). According to Akinade, Sokan and Osarenren (2005), counselling is a process of helping an individual become fully aware of himself and the ways in which he is responding to the influences of his environment. Counselling is a two-way professional and humane interaction between a trained therapist (called a counsellor) and one or more individuals (called counselees/clients) who cannot resolve, on their own, certain normal everyday problems in any of educational, vocational and socialpersonal aspects of their lives (Akinade, 2001). Counselling assists the individual to establish some personal meaning for his behaviour and to develop and clarify a set of goals and values for future behaviour. Therefore counselling is the heart of the work of guidance and counselling which is concerned with feelings, attitudes and emotional dispositions of an individual about himself and the situation facing him.

Guidance and counselling is based on the assumption that every individual in any society has had, is having and will have a problem that he alone could not solve (Makinde, 1987). Guidance and counselling is a professional field that has a broad range of activities and services aimed at assisting individuals to understand themselves, their problems, their school environment and their world (Egbochuku, 2008). Okobiah and Okorodudu (2004) stated that guidance and counselling has been conceptualized as a programme of activities which has provided us with the gateway out of the existing numerous problems in our present age of complex scientific and technological 
development. Guidance and counselling has become the remedy to current challenges human beings face due to the scientific and technological development. Idowu (2004) views guidance and counselling as a process of planned intervention within a school system by which the total development of students are stimulated in areas relating to their personal, social, career, emotional and academic concerns.

In the Colleges of Education, even teacher-trainees who feel happy and are in control of themselves have their moments of doubts and despair. Guidance services will help these students prepare for life in and after tertiary education, whether or not they will get jobs, getting married and living independent and valuable life (Unachukwu \& Igborgbor, 1991). According to Gumisiriza (2012), guidance services are widely known to be beneficial in shaping and decision making capabilities of both students and people at work places. Guidance and counselling is therefore essential to help remedy teacher-trainees' challenges that may arise in Colleges of Education. Guidance services may be defined as a professional aid to individuals and small groups in dealing with commonly recurring personal, educational and vocational needs and problems. Garba (2013) is of the view that benefits of a comprehensive school counselling programme should include the promotion of vigorous academic pursuit for all students, preparation of students for challenges of adult life, relating educational programmes to future success and providing strategies for closing the achievement gap. Guidance and counselling programmes also help students to develop decision-making and problem-solving skills.

According to Nyarko-Sampson (2010), there are various needs of students in educational institutions but many students are usually unable to meet their needs and they become perplexed, disappointed, confused and frustrated especially when they experience failure in their studies. Some students come to Colleges of Education as a last resort, others by influence from parents and other relations. Some still appear to be disillusioned and ignorant about the profession they are being trained for. These and many others make teacher-trainees quite unfocused, leading to various misbehaviours and crises, which could be prevented with effective guidance and counselling programmes. Personally, counselling and guidance services help the individual to know and understand himself, accept his superior and limited features and develop himself, trust himself, develop effective interpersonal relationships, become a personally and socially balanced and harmonious individual (Yesilyaprak, 2001). Educationally, guidance services help the students adapt to school make educational decisions and choices by informing them about educational facilities (Ilgar, 2004). Maluwa-Banda (1998) states that guidance services help students understand their own interests, abilities and potentialities and develop them to the fullest which also helped students to identify vocational opportunities.

A large number of students in Colleges of Education in Ghana find themselves in the grips of personal adjustment problems, economic problems; interpersonal problems arising from peer group influence such as smoking, problems from the opposite sex, poor self-concept, and educational problems such as inability to cope with course requirements and adjustment to institutional code of ethics among others (Nyarko-Sampson 2013). The school guidance and counselling is aimed at providing counselling, appraisal, orientation, consultation, placement, information and follow-up services to students among other things (GES as cited in Amenyedzi, 1997).

However, in most schools, there are no systematic Guidance services (GES, 2003, p.3). Empirical research findings actually corroborate the GES's observations, for instance Braimah (2010) assessed guidance services in Senior High Schools in the Tamale Metropolis and found that the information, appraisal, placement, evaluation, consultation and referral services were inadequately provided. According to Ackom (1992), research findings on guidance services at the Colleges of Education level appear to be scanty as of now, maybe due to the fact that guidance itself is relatively new in Ghana. Mensah (2007) studied the place of guidance and counselling in Colleges of Education in the Eastern Region of Ghana and found that most College of Education students did not benefit from the guidance and counselling programmes, whilst some Colleges of Education had no laid down systems and structures that promoted guidance and counselling. In evaluating guidance and counselling programmes in Colleges of Education in the Eastern and Greater Accra zones, Nyarko-Sampson (2010) reported that even though guidance services exist in the colleges, teacher-trainees do not patronize. The study further established that guidance services offered in the colleges were orientation, counselling, consultation and information.

Nyan (2014) conducted a study on students' and teachers' perception of guidance and counselling service in secondary schools in Eastern Uganda and found that students and teachers generally have a positive perception about the necessity of counselling service in secondary. Some research studies in guidance and counselling in Colleges of Education in Ghana include: Teacher-trainees' appraisal of guidance and counselling programmes in Colleges of Education in Ghana: A study of selected colleges in the Eastern and Greater Accra zones (NyarkoSampson, 2010) which found that evaluation, placement, appraisal and follow-up service were not offered. Tutors' participations in guidance and counselling programme in Colleges of Education in Northern Ghana (NyarkoSampson, 2013) which concluded among other things that there is inadequate provision of guidance information materials as well as lack of accommodation to support guidance and counselling programmes.

Sedofia and Ocansey (2013) conducted a study to evaluate the information and consultation services in the Colleges of Education in the Volta Region of Ghana. Based on their findings, it was concluded that both 
information and consultation services were not rendered very well to benefit students; likewise the personnel who work as counsellors in the colleges surveyed are not professionally trained and qualified. Sedofia (2011) evaluated guidance and counselling programme in Colleges of Education in Volta Region of Ghana and found that counselling, appraisal, consultation, placement and information services were provided to a lesser extent in the colleges. The study further recognized that guidance and counselling in general was not benefiting students as it should.

The findings of Mensah (2007), Sedofia and Ocansey (2013) revealed that orientation, consultation, appraisal, counselling, information and placement services were offered in schools and colleges while follow-up and evaluation services were not administered. These findings of their studies go to support the fact that institutions see the need for guidance services and various attempts are made by principals, headmaster as well as teachers to institute guidance services. The purpose is to help students to make meaningful adjustment in the school situation and also to help them develop their potentialities. Aidoo (2011) conducted a study on the administration of guidance and counselling in the Colleges of Education in Ghana. The findings revealed that tutors and students rated the introduction of guidance and counselling programme as good but not satisfied with its administration therefore want an improvement. Also orientation and counselling are the popular guidance services rendered to students in the colleges which denied them from benefiting from other guidance services. It was against this research finding that teacher-trainees" perceptions of guidance services needed to be investigated in order to assist them make wise, informed and realistic decisions on their personal, social, educational and vocational choices. These empirical research findings reveal the lapses in guidance and counselling programmes offered in the Colleges of Education in Ghana. This phenomenon prompted the researcher to conduct this study to find out teacher-trainees' perception of guidance services in Colleges of Education in the Volta Region.

Purpose of the Study

The general purpose of this study was to find out teacher-trainees' perception of guidance services offered in Colleges of Education in the Volta Region of Ghana. Specifically, the study sought to:

1. determine teacher-trainees' perception of the availability, accessibility, benefits and confidentiality of guidance services in the Colleges of Education in the Volta Region.

2. find out if the guidance services provided meet the needs of teacher-trainees.

3. investigate the extent to which teacher-trainees patronize guidance services.

Research Hypotheses

The following null and alternative hypotheses were generated to guide the study:

$\mathrm{H}_{0.1}$ There is no statistically significant difference in teacher-trainees' perception of the availability, accessibility, benefits and confidentiality about guidance services offered at the colleges of education in the Volta Region on the basis of grade level.

$\mathrm{H}_{1}$ There is statistically significant difference in teacher-trainees' perception of the availability, accessibility, benefits and confidentiality about guidance services offered at the colleges of education in the Volta Region on the basis of grade level.

$\mathrm{H}_{0.2}$ There is no statistically significant difference between male and female teacher-trainees' perception of the availability, accessibility, benefits and confidentiality of guidance services offered at the Colleges of Education in the Volta Region.

$\mathrm{H}_{1}$ There is statistically significant difference between male and female teacher-trainees' perception of the availability, accessibility, benefits and confidentiality of guidance services offered at the Colleges of Education in the Volta Region.

$\mathrm{H}_{0.3}$ There is no statistically significant difference between the guidance needs of male and female teachertrainees in the colleges of education in the Volta Region.

$\mathrm{H}_{1}$ There is statistically significant difference between the guidance needs of male and female teacher- trainees in the colleges of education in the Volta Region.

$\mathrm{H}_{0.4}$ There is no statistically significant difference between male and female teacher-trainees in the reasons they give for not patronizing guidance service in the Colleges of Education in the Volta Region.

$\mathrm{H}_{1}$ There is statistically significant difference between male and female teacher-trainees in the reasons they give for not patronizing guidance service in the Colleges of Education in the Volta Region.

\section{Research Methods}

Research Design

The study is a quantitative research which adopted descriptive survey design. Descriptive research, according to Williams (2007), involves the identification of attributes of a particular phenomenon based on an observation, or the exploration of correlation between two or more phenomena. Survey research involves acquiring information about one or more groups of people perhaps about their characteristics, opinions, attitudes, or previous experiences by asking questions and tabulating their answers (Leedy \& Ormrod, 2005). Survey design makes it relatively easy to collect data on attitudes and opinions from large samples of subjects (Weiten, 2001). 


\section{Population}

According to Creswell (2012, p. 142), 'population is a group of individuals who have the same characteristics'. The target population for the study was 5832 comprising students and guidance and counselling coordinators in 7 Colleges of Education in Volta Region (Amedzofe E. P. College of Education (AMECO), St. Francis College of Education (FRANCO), Jasikan College of Education (JASICO), St. Teresa College of Education (TERESCO), Peki College of Education (GOVCO), Dambai College of Education (DACE) \& Akatsi College of Education (AKATSICO), 2015). The accessible population for the study is 3,500 students (level 100, 200 and 300) in the 7 Colleges of Education in Volta Region (AMECO, FRANCO, JASICO, TERESCO, GOVCO, DACE \& AKATSICO, 2015).

Sample and sampling procedure

A sample of three hundred and forty six (346) respondents out of the total accessible population of 3,500 students was selected in accordance with Krejcie and Morgan's (as cited in Sarantakos, 2005) determination of sample size for research activities. This sample was taken based on Krejcie and Morgan's Table of Sample Sizes (S) required for given Population Sizes (N). The Table indicates that for a population of 3,500, three hundred and forty six (346) could be selected as sample sizes at 0.05 significant level (as cited in Sarantakos, 2005).

A multi-stage sampling procedure was adopted in selecting the samples for the study. Purposive sampling procedure was used to select the seven colleges. Purposive sampling is a qualitative sampling procedure in which researchers intentionally select individuals or sites to learn about or understand the central phenomenon (Creswell, 2012). Ary, Jacobs and Sorensen (2010), states that quota sampling involves selecting typical cases from diverse strata of a population. The quota sampling was used by considering the total number of students in each college and the corresponding percentages of the sample population. Again quota sampling was used to select students from each grade level in each college. The students were stratified into male and female. The number of students from each college that was included in the sample was based on the proportion of male and female students amongst the 346 sampled. For example 346 sample of students, the sample is made up of $51 \%$ females and $49 \%$ males. This worked out to 176 female and 170 male students. The participants to take part in the research were invited until each of the quotas was filled. According to Creswell (2012), simple random sampling is a sampling technique whereby the researcher selects participants (or units, such as schools) for the sample so that every individual has an equal probability of being selected from the population. The researcher used simple random sampling to select the first and second year students in each college to respond to the questionnaires. This is to give students equal chance of being selected to be part of the study to avoid biases in the selection process (Fraenkel $\&$ Wallen, 2003). However convenience sampling was used to select the final year students because they were at their various out-stations for teaching practice.

Table 1. Distribution of student population and sample by college

\begin{tabular}{|l|c|c|c|c|}
\hline \multirow{2}{*}{ College } & \multirow{2}{*}{ Population } & \multicolumn{2}{|c|}{ Gender } & \multirow{2}{*}{ Sample } \\
\cline { 3 - 4 } & & Male & Female & \\
\hline FRANCO & 973 & 543 & 430 & 53 \\
\hline JASICO & 952 & 652 & 300 & 52 \\
\hline GOVCO & 846 & 500 & 346 & 50 \\
\hline DATCO & 775 & 425 & 350 & 49 \\
\hline AMECO & 769 & 439 & 330 & 48 \\
\hline TERESCO & 755 & 0 & 755 & 47 \\
\hline AKATSICO & 755 & 420 & 335 & 47 \\
\hline Total & 5825 & 2979 & 2846 & 346 \\
\hline
\end{tabular}

Source: student registers of AMECO, FRANCO, JASICO, TERESCO, GOVCO, DACE and AKATSICO for 2015/2016 academic year.

Research Instruments

The instrument that was used to collect data was the questionnaire which was self-developed. The questionnaire comprised 55 items, which were categorized into three sections namely A, B, and C. Section A requested the respondents' biographic data, Section B measured the extent to which the respondents agree to statements made on the perception, types and provision of guidance services. Section B statements/items were constructed in a 4Point Likert Type Scale. The Likert scaling is most frequently and appropriately applied to attitude, opinions and beliefs scaling technique in educational research (UNESCO, 2005). Section C gives the respondents the opportunity to supply short responses to items which seek data on the patronage and effective delivery of guidance services.

The reliability measure established for the instrument was internal consistency through a pre-test. The reliability of the instrument is 0.89 alpha. This was estimated using the Cronbach's Alpha Coefficient. The research instrument's alpha coefficient value of 0.89 was above 0.7 , the recommended reliability value (Cronbach, 1970). This shows that the questionnaire is highly reliable. Content validity measure was adopted for the study. Stangor 
(2004) opined that content validity is one of the most powerful techniques available to the researcher through which data gathering instruments like questionnaire can be validated. The instrument was discussed with the Supervisors, and an expert in the field of measurement and evaluation for scrutiny, review and judgment of its appropriateness. The researcher incorporated the necessary suggestion and corrections on the instrument before administering the questionnaire.

Data Collection Procedure

The questionnaire forms were personally administered to the respondents by the researcher with the assistance of one trained research assistant. The selected students assembled in their respective lecture hall where the students were made to read through the questionnaires, after they were briefed, and allowed to seek clarification on issues they do not understand. The completed forms were collected on the same day. This helped to achieve a high return rate $(99 \%)$ of the instrument.

Data analysis

Data from the questionnaires was analyzed using the Statistical Packages for Social Sciences (SPSS) software application. The analysis and interpretation of Hypothesis 1 was analyzed using One-Way Analysis of Variance (ANOVA) and Hypotheses 2, 3, 4 were analyzed using independent sample t-test.

\section{Result and Discussions}

Hypothesis One: There is no statistically significant difference in teacher-trainees' perception of the availability, accessibility, benefits and confidentiality about guidance services offered at the Colleges of Education in the Volta Region on the basis of grade level.

This hypothesis sought to find out whether there is statistically significant difference between teacher-trainees' perception of guidance services on the basis of level of study. The hypothesis was tested using ANOVA. The results are represented in Table 2

Table 2. Analysis of Variance (ANOVA) results on teacher-trainees' perception of the availability, accessibility, benefits and confidentiality about guidance services offered at the Colleges of Education in the Volta Region on the basis of level of study

\begin{tabular}{|l|l|l|l|l|l|}
\hline & Sum of Squares & Df & Mean Square & F & Sig. \\
\hline Between groups & 87.285 & 2 & 43.642 & 3.154 & .044 \\
\hline Within groups & 4746.241 & 343 & 13.837 & & \\
\hline Total & 4833.526 & 345 & & & \\
\hline
\end{tabular}

$\mathrm{p}<.05$ significant level

Table 2 indicates a one-way ANOVA which was conducted to compare the teacher-trainees' perception of guidance services on the basis of levels (100, 200 and 300). There was statistically significant difference between teacher-trainees' perception of guidance and counselling service at $\mathrm{p}<.05$ alpha level for the three levels [F (2.343) $=3.154, p=0.044]$. The probability value ( $p$-value) of 0.044 is less than the 0.05 significant level. Therefore, based on the results in Table 2 the null hypothesis is rejected and the study concluded that there exists a statistically significant difference between teacher-trainees' perception of guidance and counselling on the bases of level of study.

Nevertheless, it was not clear whether the differences were significant in the three levels of study. To establish whether there existed any significant difference in the three levels in the colleges, the ANOVA results were subjected to the post-hoc test shown in Table 3.

Table 3. Post-Hoc Test (Tukey HSD) for teacher-trainees' perception of the availability, accessibility, benefits and confidentiality about guidance services offered at the colleges of education in the Volta Region on the basis of grade level

\begin{tabular}{|c|c|c|c|c|c|c|}
\hline \multirow[b]{2}{*}{ (I)Level } & \multirow[b]{2}{*}{$(\mathrm{J})$ Level } & \multirow[b]{2}{*}{ Mean Difference(I-J) } & \multirow[b]{2}{*}{ Std. Error } & \multirow[b]{2}{*}{ Sig. } & \multicolumn{2}{|c|}{ 95\% Confidence Interval } \\
\hline & & & & & Lower Bound & Upper Bound \\
\hline \multirow[t]{2}{*}{100} & 200 & .66822 & .46458 & .322 & -.4254 & 1.7618 \\
\hline & 300 & $1.30548^{*}$ & .52300 & .035 & .0744 & 2.5366 \\
\hline \multirow[t]{2}{*}{200} & 100 & -.66822 & .46458 & .322 & -1.7618 & .4254 \\
\hline & 300 & .63726 & .50675 & .420 & -.5556 & 1.8301 \\
\hline \multirow[t]{2}{*}{300} & 100 & $-1.30548^{*}$ & .52300 & .035 & -2.5366 & -.0744 \\
\hline & 200 & -.63726 & .50675 & .420 & -1.8301 & .5556 \\
\hline \multicolumn{6}{|c|}{ *. The mean difference is significant at the 0.05 level. } & \\
\hline
\end{tabular}

Table 3 presents Post hoc comparisons using the Tukey HSD test indicated that the mean score for the level $100(\mathrm{M}=30.29, \mathrm{SD}=3.23)$ was statistically significant difference than the level $200(\mathrm{M}=28.98, \mathrm{SD}=3.54)$. However, the level $300(\mathrm{M}=29.62, \mathrm{SD}=4.18)$ did not significantly differ from Level 100 and Level 200. These 
results suggest that the level of difference in perception of guidance services comes from level 100. This may be due to the fact that the level 100 who are the first years were newly admitted and do not have enough encounter with the counsellor like other grade levels.

Hypothesis Two: There is no statistically significant difference between male and female teacher-trainees' perception of the availability, accessibility, benefits and confidentiality of guidance services offered at the Colleges of Education in the Volta Region.

This hypothesis sought to find out whether there is statistically significant difference between male and female teacher-trainees perception in relation to guidance services in Colleges of Education in the Volta Region. Table 4 presents the results.

Table 4. T-test Results of Male and Female Teacher-trainees' Perception of the Availability, Accessibility, Benefits and Confidentiality of Guidance Services

\begin{tabular}{|c|c|c|c|c|c|c|c|}
\hline Scale & Gender & $\mathrm{N}$ & Mean & SD & $\mathrm{T}$ & Df & $\mathrm{P}$ \\
\hline \multirow{2}{*}{$\begin{array}{l}\text { Teacher-trainees } \\
\text { Perception }\end{array}$} & Male & 170 & 29.5412 & 3.67803 & -.744 & 344 & .457 \\
\hline & Female & 176 & 29.8409 & 3.80942 & & & \\
\hline
\end{tabular}

p>.05 significant level

Table 4 presents an independent sample t-test on perception of guidance services in male and female teachertrainees in Colleges of Education in Volta Region, Ghana. There was no statistically significant difference between the scores for male $(M=29.54, S D=3.68)$ and female $(M=29.84, S D=3.81)$ perception, $\mathrm{t}(34)=-0.74, p=$ 0.46 . The probability value ( $\mathrm{p}$-value) of 0.46 is greater than the 0.05 significant level. From Table 3 results the null hypothesis failed to be rejected. The study concludes that gender does not have an effect on teacher-trainees perception of guidance services. Specifically, the result indicates that male and female teacher-trainees perception of guidance services are the same in Colleges of Education in Volta Region, Ghana. This may be due to the fact that both male and female teacher-trainees look at guidance and counselling as tool for personal, social and psychological development. Hence the counsellor's ability to implement effective guidance and counselling service would make students have good or bad perception about the programme. Yuksel-Sahin (2009) conducted a study and found no statistically significant difference regarding the evaluation of counselling and guidance services according to gender. This research finding was consistent with the results of this study.

Hypothesis Three: There is no statistically significant difference between the guidance and counselling needs of male and female teacher-trainees in the colleges.

This hypothesis sought to find out whether there is statistically significant difference between male and female teacher-trainees in relation to their guidance and counselling needs in Colleges of Education in the Volta Region. Table 5 presents the result.

Table 5. T-test results of male and female teacher-trainees' guidance and counselling needs

\begin{tabular}{|c|c|c|c|c|c|c|c|}
\hline Scale & Gender & $\mathrm{N}$ & Mean & SD & $\mathrm{T}$ & Df & $\mathrm{P}$ \\
\hline Guidance & and Male & 170 & 23.6647 & 4.88803 & 1.367 & 344 & .172 \\
\hline Counselling Needs & Female & 176 & 22.9602 & 4.69451 & & & \\
\hline
\end{tabular}

$\mathrm{p}>.05$ significant level

Table 5 shows analysis of guidance and counselling needs between male and female teacher-trainees in Colleges of Education in Volta Region, Ghana. The results showed that there was no statistically significant difference between the scores for male $(M=23.66, S D=4.89$ and female $(M=22.96, S D=4.69)$ needs, $t(34)=$ $1.37, p=0.17$. The probability value ( $p$-value) of 0.17 is greater than the 0.05 significant level. From these results the null hypothesis failed to be rejected and the study concluded that gender does not have an effect on teachertrainees guidance and counselling needs. Specifically, the result indicates that male and female teacher-trainees' guidance and counselling needs are the same in the Colleges of Education in Volta Region, Ghana. This implies all the guidance and counselling needs must be adequately provided to both male and female teacher-trainees devoid of special attention to a particular gender group. This finding disagreed with Guneri, Aydin \& Skoyholt, (2003) study which found gender differences in guidance and counselling needs of students. Male students were found to express a significantly greater concern for family issues, while female students were more concerned about serf-control and personal issues.

Hypothesis Four: There is no statistically significant difference between male and female teacher-trainees in the reasons they give for not patronizing guidance service in the Colleges of Education in Volta Region.

This hypothesis sought to find out whether there was statistically significant difference between male and female teacher-trainees' reason for not patronizing guidance services provided in Colleges of Education in the Volta Region. The Independent samples t-test was used to test the hypothesis. Table 6 indicates the result 
Table 6. T-test results of male and female teacher-trainees' reasons for not patronizing guidance services

\begin{tabular}{llllllll}
\hline Scale & Gender & $\mathrm{N}$ & Mean & SD & T & Df & P \\
\hline Reasons for not patronizing & Male & 170 & 3.55 & 2.140 & 1.977 & 334.609 & .049 \\
& Female & 176 & 3.12 & 1.872 & & & \\
\hline
\end{tabular}

$\mathrm{p}<.05$ significant level

Table 6 indicates the results of teacher-trainees' reasons for not patronizing guidance services in male and female teacher-trainees in Colleges of Education in Volta Region, Ghana. There was statistically significant difference between the scores for male $(\mathrm{M}=3.55, \mathrm{SD}=2.14$ and female $(\mathrm{M}=3.12, \mathrm{SD}=1.87)$ reasons, $\mathrm{t}(33)=$ $1.98, p=0.049$. The probability value ( $p$-value) of 0.049 is less than the 0.05 significant level. Therefore, based on the results in Table 6 the null hypothesis is rejected. The study concludes that teacher-trainees' reason for not patronizing guidance services differs on the basis of gender. This result is probably because female students are perceived as more socially competent or better adjusted to share issues than males who are reserved. This call for Duku's (1991) recommendation that students should be encouraged to patronize guidance services since they stand to benefit from the programme. Similarly the finding buttressed Nyarko-Sampson (2010) study that even though guidance services exist in the colleges, teacher-trainees do not patronize.

\section{Conclusion}

The main conclusion of the study is that teacher-trainees in Colleges of Education in the Volta Region perceived guidance services as not effectively delivered.

1. The study concludes that there is statistically significant difference in teacher-trainees perception of guidance services of the basis of levels. This may be due to the fact that the level 100 teacher-trainees who are the first years were newly admitted and do not have enough encounter with the counsellor like other grade levels.

2. There was no statistically significant difference in teacher-trainees' perception of guidance services with regards to gender. This implies that both male and female teacher-trainees look at guidance and counselling as tool for personal, social and psychological development.

3. There was no statistically significant difference in teacher-trainees' guidance and counselling needs on the basis of gender. The study concluded that male and female teacher-trainees' guidance and counselling needs are the same in the Colleges of Education in Volta Region, Ghana.

4. However there was statistically significant difference in the reasons for not patronizing guidance services on the basis of gender. This due to fact that female students are perceived as more socially competent or better adjusted to share issues than males who are reserved.

\section{Recommendations}

On the basis of the conclusion drawn from the key findings of the study, the following recommendations were made:

1. Ghana Education Service should organize in-service training programmes for counsellors in the colleges and other schools to help equipped, refreshed knowledge and sharpened the skills of the counsellors. This is to help counsellors make services available to teacher-trainees at all levels to help them have good perception about the guidance services.

2. Counsellors in collaboration with College Authorities, Parent Teacher Association and NonGovernmental Organizations should assist in the publicity of guidance and counselling programme periodically. This will help male and female teacher-trainees' have good perception of guidance services in the colleges.

3. The Ghana Education Service should ensure that trained and qualified counsellors are posted to the colleges with well-equipped counselling centres within the shortest possible time will help to provide effective guidance and counselling that will meet the needs of teacher-trainees in Colleges of Education in the Volta Region Ghana.

4. It is recommended that counsellor explore and employ all strategies including the skill of persuasive invitation to get both male and female students to patronized guidance services especially the male students.

\section{Acknowledgements}

I would like to express my sincere gratitude to my supervisors, Prof. Eric Nyarko-Sampson and Dr. John Ofori Attram both of the Counselling Centre, University of Cape Coast (UCC), for their professional guidance, advice, encouragement and the goodwill with which they guided this work. I am very grateful.

I am also grateful to Prof. G. A. Kankam of the University of Education, Winneba, Mr. S. DohFia of the Department of Educational Foundations, UCC. Dr. J. Sedofia and Ms J.E.A. Dorleku of St. Francis College of Education, Hohoe for their generous contributions toward the successful completion of the work. 
I am again grateful to Prof. C. D. Adzobu of Evangelical Presbyterian University College, Ho for his unflinching support throughout my life.

My sincerest thanks also go to the Principals, students and counsellors of the Colleges of Education in the Volta Region for their cooperation in conducting the study.

Finally, I wish to thank my family and friends for their support, especially, my wife Mrs. Edem TsawodziAdzakpa. Thanks for being there when the going got tough. God bless you.

\section{REFERENCE}

Ackom, P. E. (1992). Secondary school students' perception of guidance coordinators: A study in the Western Region of Ghana. Unpublished Master's Thesis, University of Cape Coast, Cape Coast, Ghana.

Aidoo, J. (2011). Administration of guidance and counselling in the colleges of education in Ghana. Unpublished Master's Thesis University of Cape Coast, Cape Coast Ghana.

Akatsi College of Education (AKATSICO) (2014). Student registers for the 2014/2015 academic year. AKATSICO, Akatsi: Author.

Akinade, E. A. (2001). Modern concise dictionary psychology. Logos: Pumark Nigeria Ltd.

Akinade, E. A., Sokan, B. O. \& Osareren, N. (2005). An Introduction to guidance and counselling, Nigeria: A basic text for college and University. Caltop Publication.

Amenyedzi, F. W. K. (1997). An evaluation of the guidance programme of senior secondary schools in the Ketu and Keta districts. Unpublished master's thesis, University of Cape Coast, Cape Coast, Ghana.

Ary, D., Jacobs, L. C. \& Sorensen, C. (2010). Introduction to research in education ( ${ }^{\text {th }}$ Ed.). USA: Wadsworth.

Biswalo, P. M. (1996). Introduction to guidance and counselling in African setting. Dar-es Salaam: University Press.

Braimah, M. (2010). Assessment of guidance and counselling services in senior high schools in Tamale metropolis. Unpublished undergraduate research project, University of Education, Winneba: Ghana.

Corey, G. (2009). Theory and practice of counselling and psychotherapy ( $8^{\text {th }}$ Ed.). United State of America: Brooks/Cole.

Corsini, R. J. \& Wedding, D. (2000). Current psychotherapies (6 ${ }^{\text {th }}$ Ed.). United State of America: F. E. Peacock Publisher, Inc.

Creswell, J. W. (2012). Educational research: Planning, conducting and evaluating qualitative research. London: Pearson Education Ltd.

Cronbach, L. J. (1970). Essentials of psychological testing (3 ${ }^{\text {rd }}$ Ed.). New York: Harper \& Row.

Dambai College of Education (DACE) (2014). Student registers for the 2014/2015 academic year. DACE, Dambai: Author.

Egbochuku, E. O. (2008). Assessment of the quality of guidance and counselling services to students' adjustment in secondary schools in Edo State of Nigeria. Research Journal of International Studies, 8: 42-50.

Essuman, J. K. (2015). Tracing our roots: The history of guidance and counselling in Ghana. Paper presented at the $1^{\text {st }}$ National Conference of Guidance and Counselling in Ghana, organized by Counselling Centre, March $10^{\text {th }}-12^{\text {th }}, 2015$ University of Cape Coast, Cape Coast.

Essuman, J. K. (2007). Guidance and counselling in contemporary Ghanaian society. J. Couns. Educ. Psychol., 1(2): $140-160$.

Evangelical Presbyterian College of Education (AMECO) (2014). Student registers for the 2014/2015 academic year. AMECO, Amedzofe: Author

Eyo, M. B., Joshua, A. M. \& Esuong, A. E. (2010). Attitude of secondary school students towards guidance and counselling services in Cross River State. Edo Journal of Counselling, 3 (1): 87-99.

Farrant, J. S. (2004). Principles and practice of education. London: Longman Group UK Ltd

Fraenkel, J. R. \& Wallen, N. E. (2002). How to design and evaluate research in education (5 ${ }^{\text {th }}$ Ed.). Boston: McGraw-Hill.

Frankl, V. (1978). The unheard cry for meaning. New York: Simon \& Schuster (Touchstone).

Garba, A. (2013). Imperatives of programming in guidance and counselling in higher education. Keynote address presented on occasion of formal presentation of benchmark statements on student support services and guidelines on counselling and Human Development Centres in Nigeria universities, organized by University Commission (NUC), January 15, 2013.

Gumisiriza, J. (2012). Orphan care organization. Abba home orphanage.

Guneri, O. Y., Aydin, G., \& Skovholt, T. (2003). Counselling needs of students and evaluation of counselling services at a large urban university in Turkey. International Journal for the Advancement of Counselling, 25(1), 53-63.

Gysbers, N. C. \& Henderson, P. (2001). Developing and managing your school guidance programme ( $3^{\text {rd }}$ Ed.). Alexandria, VA: American Counselling Association.

Idowu, A. I. (2004). Guidance and counselling in education ( $2^{\text {nd }}$ Ed.). Ilorin: Indemac (Nigeria Publishers) Limited. 
Ilgar, Z. (2004). Rehberligin Baslica Turleri (The Main Types of Guidance). (G. Can, Trans.). Psikolojik Danısma ve Rehberlik. Ankara: Pegem Yayincilik.

Jasikan College of Education (JASICO) (2014). Student registers for the 2014/2015 academic year. JASICO, Jasikan: Author.

Krejcie, R. V. \& Morgan, D. W. (1970). Determining sample size for research activities. Educational and Psychological Measurement, 30, 607-610.

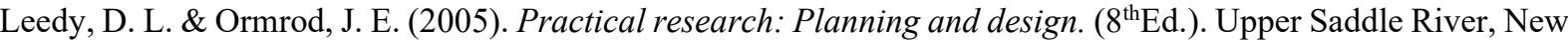
Jersey: Merrill/Prentice Hall.

Lunenburg, F. C. (2010). School guidance and counselling services. Journal of Schooling, 1(1), 1-9.

Makinde, O. (1987). Fundamentals of guidance and counselling. London and Basingstoke: Macmillan Education Ltd.

Maluwa-Banda, D. W. (1998). School counsellors' perception of guidance and counselling programme in Malawi's secondary schools. British Journal of Guidance and Counselling, 26(2), 287-295.

May, R. (1967). Psychology and the human dilemma. Princeton, NJ: Van Nostrand.

May, R. \& Yalom, I. (2005). Existential psychotherapy. In Corsini, R. J. \& Wedding, D. (Eds.), Current psychotherapies $\left(7^{\text {th }}\right.$ Ed.). Belmont, CA: Broks/Cole.

Mensah, A. E. (2007). The place of guidance and counselling in teacher training colleges in the Eastern Region of Ghana. Unpublished Master's Thesis, University of Education, Winneba, Ghana.

Numale, K. M. (2007). Guidance and counselling in education. Cape Coast: Yaci Publications.

Nyarko-Sampson, E. (2010). Teacher trainees' appraisal of guidance and counselling programmes in colleges of education in Ghana: a study of selected colleges in the Easter and Greater Accra zones. The Nigerian Journal of Guidance and Counselling 15 (1), 95-110.

Nyarko-Sampson, E. (2013). Tutors' participation in guidance and counselling programmes in colleges of education in northern Ghana. Ife Psycholo GIA 21 (2), 141-149.

Obadofin, B. (1997). Guidance or counselling foundation. Oyo State: Newborne Enterprise.

Okobiah, O. C. \& Okorodudu, R. I. (2004). Issues, concepts, theories and techniques of guidance and counselling, Benin City: Ethiope Publishing.

Oniye, A. O. \& Alawaye, A. S. (2008). Female Students' Perceived Causes and Solutions to Examination Malpractice in ASA Local Government: Implications for Counselling. Sokoto Educational Review, 10 (2):116.

Peki College of Education (GOVCO) (2014). Student registers for the 2014/2015 academic year. GOVCO, Peki: Author.

Rutondoki, E. N. (2001). Guidance and counselling. Makerere University: Adult and Continuing Education.

Sedofia, J. \& Ocansey, F. (2013). An evaluation of the information and consultation services in the colleges of education in the Volta Region of Ghana. Educational Research. 4(9), 674-681.

Satre, J. P. (1956). Being and nothingness. New York: Philosophical Library.

Sarantakos, S. (2005). Social research ( $3^{\text {rd }}$ Ed.). Houndmils: Macmillan Press Ltd.

Sedofia, J. (2011). An evaluation of guidance and counselling programme in the Colleges of Education in the Volta Region of Ghana. Unpublished Master's Thesis University of Cape Coast, Cape Coast Ghana.

Shertzer, B. \& Stone, S. (1976). Fundamentals of counselling. Boston: Houghton Mifflin Co.

Stangor, C. O. (2004). Research methods for behavioural sciences. Boston: Hougton Mifflin Co.

St. Francis' College of Education (FRANCO) (2014). Student registers for the 2014/2015 academic year. FRANCO, Hohoe: Author

St. Teresa College of Education (TERESCO) (2014). Student registers for the 2014/2015 academic year. TERESCO, Hohoe: Author

Taylor, A. I., \& Buku, D. K. (2006). Basics in guidance and counselling Winneba: Department of Psychology and Education, University of Education.

Unachukwu, G. C., \& Igborgbor, T. (1991). Guidance and counselling: A realistic approach. Nigeria: International Universities Press.

UNESCO, (2005). Quantitative research methods in educational planning. Southern \& Eastern Africa: IIEP's Print shop.

Weiten, W. (2001). Psychology: Themes and variations $\left(5^{\text {th }}\right.$ Ed.). USA: Thomson Learning Inc.

Williams, C. (2007). Research methods. Journal of Business and Economic Research, 5(3), 65-67.

Yalom, I. (1980). Existential psychotherapy. New York: Basic Books.

Yesilyaprak, B. (2001). Egitimde rehberlik hizmetleri (Guidance services in education). Ankara: Nobel Yayın.

Yuksel- Sahin, F. (2009). The evaluation of counselling and guidance service based on teachers views and their prediction based on some variables. International Journal of Instruction. 2(1), 60-76. 